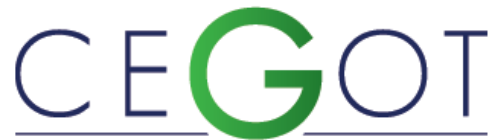

Centro de Estudos de Geografia e Ordenamento do Território
Geografia e Ordenamento do Território, Revista Eletrónica Centro de Estudos de Geografia e Ordenamento do Território http://cegot.org

BARBOSA, TAMIRES

Doutoranda em Geografia no Programa de Pós-graduação em Geografia, Universidade Federal da Paraíba

Cidade Universitária, s/n - Castelo Branco III, João Pessoa - PB, Brasil. Cep: 58051-085

mires.ufpb@gmail.com

\author{
FURRIER, MAX \\ Departamento de Geociências, Universidade Federal da \\ Paraíba \\ 58051-900, João Pessoa, Brasil \\ max furrier@hotmail.com
}

Souza, AleXANDRE

Doutorando em Geografia no Programa de Pós-graduação em

Geografia, Universidade Federal da Paraíba

58051-900, João Pessoa, Brasil

alesougeo@gmail.com

\title{
Antropogeomorfologia do município de Cabedelo - Paraíba, Brasil
}

Anthropogeomorphology of cabedelo municipality - Paraíba state, Brazil

Referência: Barbosa, Tamires; Furrier, Max; Souza, Alexandre (2018). Antropogeomorfologia do município de Cabedelo Paraíba, Brasil. Revista de Geografia e Ordenamento do Território (GOT), n. ${ }^{\circ} 13$ (junho). Centro de Estudos de Geografia e Ordenamento do Território, p. 59-83, dx.doi.org/10.17127/got/2018.13.003

\section{RESUMO}

Este trabalho objetiva realizar a caracterização e mapeamento geomorfológico do município de Cabedelo, enfocando as formas, os materiais e os processos antropogênicos. A urbanização sobre diferentes formas de relevo e determinadas unidades geológicas adquire características específicas, tanto físicas e naturais, quanto sociais. Por isso, o estudo geomorfológico em áreas urbanas é de suma importância para a tomada de decisões sobre o uso do espaço. Para o desenvolvimento do trabalho foram empregados como principais procedimentos técnicos a vetorização de cartas topográficas na escala 1:25.000, gerando produtos cartográficos derivados em escala de detalhe e inéditos, além de trabalhos de campo para coleta de informações que permitiram mapear as principais formas de relevo de origem antropogênica. Das formas antropogênicas mapeadas, podem ser citadas as áreas de degradação decorrente de mineração, os depósitos tecnogênicos e a forte alteração da planície do rio Paraíba por atividades antrópicas.

Palavras-chave: Geomorfologia antropogênica. Relevo antrópico. Antropoceno. Urbanização.

\section{ABSTRACT}

This work aims to characterize and to do a geomorphological mapping on the municipality of Cabedelo, focusing on anthropogenic forms, materials and processes. Urbanization on different landforms and particular geological units acquires specific characteristics, both physical and natural, as well as social. For this reason the geomorphological study in urban 
areas is of paramount importance for making decisions about landuse. For the development of the work, the following techniques were used as the main technical procedures: the vectorization of topographic charts in the 1: 25,000 scale, generating derived cartographic products on detailed scale and unpublished, as well as fieldwork for the collection of information that allowed mapping of the main anthropogenic landforms. The main anthropogenic forms mapped are the degradation areas due to mining, the technogenic deposits and the strong Paraíba river plain alteration by anthropic activities.

Keywords: Anthropogenic Geomorphology. Anthropic Relief. Anthropocene. Urbanization.

\section{Introdução}

O termo "Antropogeomorfologia" é utilizado para se referir a todo processo que gera formas de relevo de origem antropogênica ou à alteração de alguma geoforma já antes estabelecida, sendo a ação humana direta ou indireta (NIR, 1983). Não se refere apenas à forma resultante de um processo antrópico, mas também, à alteração do próprio processo morfogenético.

Assim, o escopo da antropogeomorfologia não inclui somente o estudo de formas de relevo produzidas pelo homem, mas também as alterações da superfície terrestre induzidas pelo homem, os fenômenos que podem perturbar o equilíbrio natural do Geossistema, bem como a formulação de propostas a fim de evitar e mitigar impactos nocivos, a exemplo dos riscos geológicos (SZABÓ, 2010).

Os estudos antropogeomorfológicos podem ser abarcados também pela geomorfologia urbana que é o estudo da urbanização sobre as formas de relevo, e pela geomorfologia antropogênica, que trata as formas produzidas ou alteradas pelo homem como relevo tecnogênico (PELOGGIA, 2005; PELOGGIA et. al, 2014 b). O termo "geomorfologia antropogênica" e sua definição pode ser encontrado em Nir (1983) que originalmente propôs o termo antropogeomorfologia, e em Rodrigues (2005), que em concordância com este e outros autores, traz orientações básicas sistematizadas e propostas, das quais destaca-se a adequação generalizada da utilização das ferramentas clássicas da geomorfologia, como a cartografia geomorfológica. 
Já o termo "tecnogênico" é empregado em virtude do atual período geológico/geomorfológico, pós-industrialização e desenvolvimento da técnica e tecnologia, que alterou substancialmente a maneira como o homem intervém na superfície terrestre, sendo, portanto, uma marca do período "Quinário" e de sua época correspondente, o "Tecnógeno" - termo utilizado para se referir à época que se caracteriza pelas condições geológico-geomorfológicas atuais, em que a ação humana ganha destaque (SILVA, 2012). Conforme aponta Baskin (2014), atualmente, a espécie humana pode ser considerada a força dominante para o modelado terrestre.

Nesta perspectiva, o homem pode ser estudado como agente geomorfológico, dono de capacidade de modificação das feições mais superficiais da crosta terrestre, na medida em que atua como agente ativo na esculturação do relevo.

Peloggia (1996; 1997; 1998; 1999; 2003; 2005) vem desenvolvendo em seus trabalhos a teoria do relevo tecnogênico. Para este autor, um dos aspectos mais significativos da ação do homem sobre a superfície da Terra é a modificação do relevo. Esta ação aparece como a expressão resultante da modificação ou "neocriação" de processos morfoesculturais e de seus depósitos correlativos, ou seja, as transformações podem ser tanto geológicas, na formação de novos depósitos sedimentares de origem antropogênica, quanto geomorfológicas, na criação das formas antropogênicas.

Os depósitos sedimentares de origem antropogênica, podem ser chamados de depósitos tecnogênicos (PELOGGIA et al, 2014 a), e podem ser classificados de diversas formas. Para este estudo são considerados quatro tipos principais de depósitos tecnogênicos, conforme Peloggia (1998), com base na caracterização do material constituinte do depósito: materiais "úrbicos" (detritos urbanos, materiais terrosos com artefatos manufaturados como tijolos, vidro, concreto...); materiais "gárbicos" (depósitos de materiais detrítico com lixo orgânico de origem humana); materiais "espólicos" (materiais terrosos escavados e redepositados por operações de terraplanagem); materiais "dragados" (materiais terrosos provenientes de dragagens de cursos de água).

Os estudos geomorfológicos nas áreas urbanas são importantes no planejamento da expansão urbana e no gerenciamento do espaço construído. Uma vez que toda construção humana se assenta sobre bases geológicas e geomorfológicas específicas e diversificadas, 
com suas características próprias e sua dinâmica evolutiva que acontece no tempo e no espaço, independente de ação humana ou não, sendo esta ação muitas vezes aceleradora da evolução dos processos geomorfológicos, tais como: erosão (processos denudacionais) e acumulação de sedimentos (processos agradacionais).

As diferentes formas de relevo podem dar às cidades características específicas que devem ser consideradas no processo de construção e expansão urbana. Assim, o relevo pode dar forma à cidade, bem como, a cidade pode reconfigurar o relevo.

O município de Cabedelo, localizado no estado da Paraíba, Nordeste do Brasil (Figura 1) consiste em uma área densamente urbanizada sobre bases geológicas compostas por sedimentos quaternários praiais e fluviais, com formas de relevo planas, caracterizadas por cordões litorâneos desenvolvidos quando do recuo do mar após a última transgressão marinha, além de planícies marinhas e planícies interdiais atuais.

A forma de ocupação urbana do município de Cabedelo, historicamente, tem modificado as margens do Rio Paraíba a oeste do núcleo urbano (Figura 1), bem como, os cordões litorâneos sobre os quais se assenta o município. Apesar de estar sobre relevos planos, a alteração morfológica da área é evidente e, em virtude disso, carece de estudos geomorfológicos pormenorizados.

Um fenômeno marcante na região está diretamente atrelado ao acelerado incremento populacional, cuja especulação imobiliária motivou a urbanização da planície litorânea e dos terraços formados pelos cordões litorâneos, produzindo nas zonas mais susceptíveis, modificações visíveis na paisagem. Faz-se necessário assim, analisar o espaço em questão sobre a ótica da antropogeomorfologia, visando corroborar com futuros planejamentos ambientais e territoriais que venham a ser executados, além de propor medidas mitigadoras de impactos ambiente ocorrentes.

\subsection{Localização da área}

O município de Cabedelo está localizado na microrregião de João Pessoa e na mesorregião da Zona da Mata Paraibana, estado da Paraíba, Nordeste do Brasil. Sua área é de 31,915 km² (IBGE, 2016). (Figura 1). 
O acesso é feito, a partir de João Pessoa, pela rodovia BR 230 e por meio do sistema de trens urbanos da CBTU que atende aos municípios de Santa Rita, Bayeux e João Pessoa. Está inserido nas Folhas SUDENE 1:25.000 de João Pessoa e Cabedelo (BRASIL, 1974). A malha urbana do município de Cabedelo é conurbada com a do município de João Pessoa a sul e sudeste. A população de Cabedelo é de aproximadamente 66.858 habitantes, configurando uma densidade demográfica elevada de $2.094,88$ hab./km².

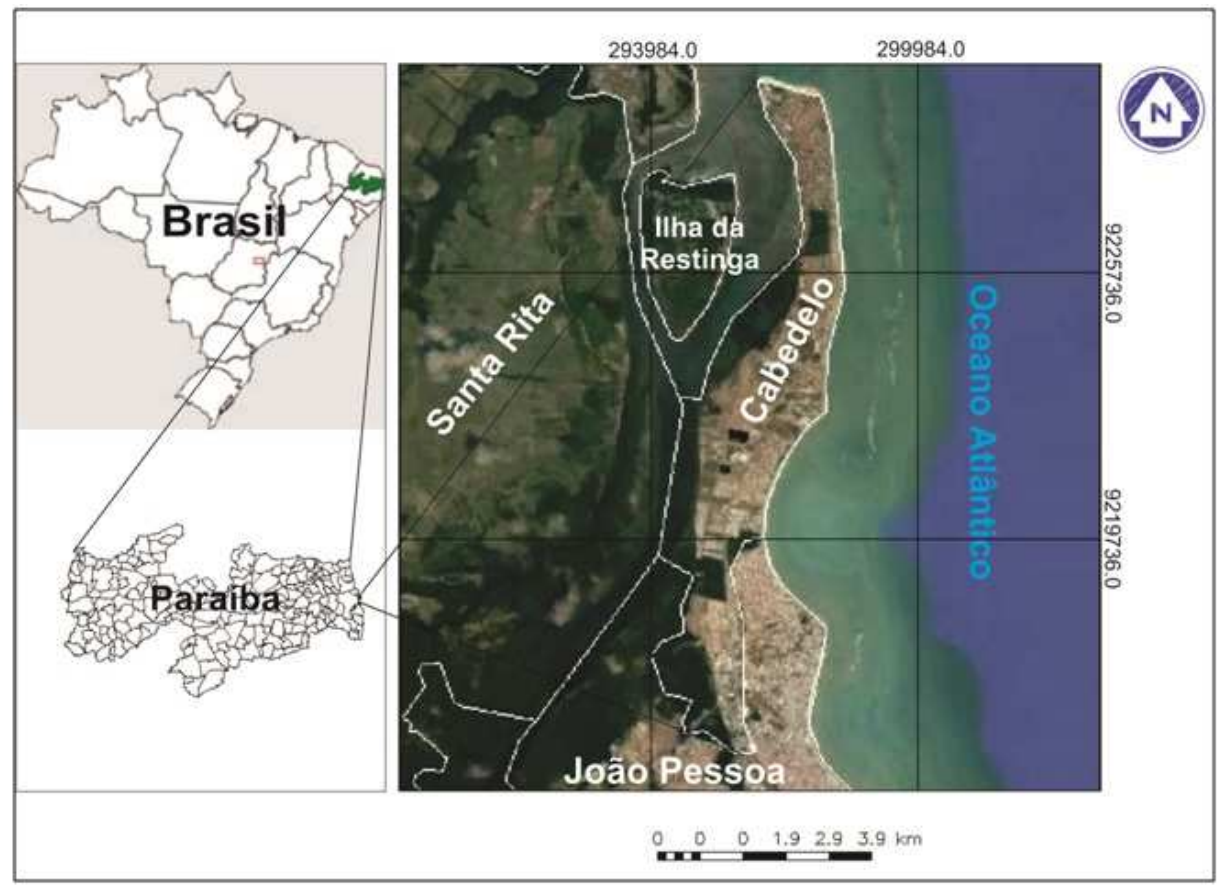

Figura 1 - Localização do município de Cabedelo.

\subsection{Aspectos fisiográficos e geológico-geomorfológicos da área}

O município de Cabedelo possui clima do tipo tropical úmido, cujas temperaturas variam entre a máxima de 31 graus celsius e mínima de 24 graus celsius. O período chuvoso se inicia em meados de fevereiro e diminui em outubro. A precipitação média anual é de aproximadamente $1.634 \mathrm{~mm}$ (INPE, 2016). Os meses mais chuvosos são abril, maio e junho.

Predominam no município ventos do quadrante sudeste o que determina o padrão predominante dos trens de ondas que atingem o litoral de forma oblíqua originando uma deriva litorânea de sentido sul-norte. Essa dinâmica acarreta um transporte sedimentar praial de sul para o norte, sendo este o principal modelador das praias do município.

A geomorfologia do município de Cabedelo consiste basicamente em três unidades principais: planícies interdiais a oeste, planícies marinhas a leste e terraços marinhos 
(cordões litorâneos) no setor central. Cabe destacar que tanto a planície marinha como a interdial são fortemente afetadas pelas marés, onde a variação diurna pode chegar a 2,8 m, classificando-a como uma mesomaré.

O mapa geológico do estado da Paraíba (CPRM, 2005) indica a unidade Qfm (depósitos quaternários flúvio-marinhos, depósitos indiscriminados de pântanos e mangues, fluviolagunares e litorâneos) como a única unidade geológica presente na área (Figura 2). Portanto, não há dúvidas da enorme generalização deste mapa o que reforça a necessidade urgente de estudos de detalhe, como é a proposta deste trabalho.

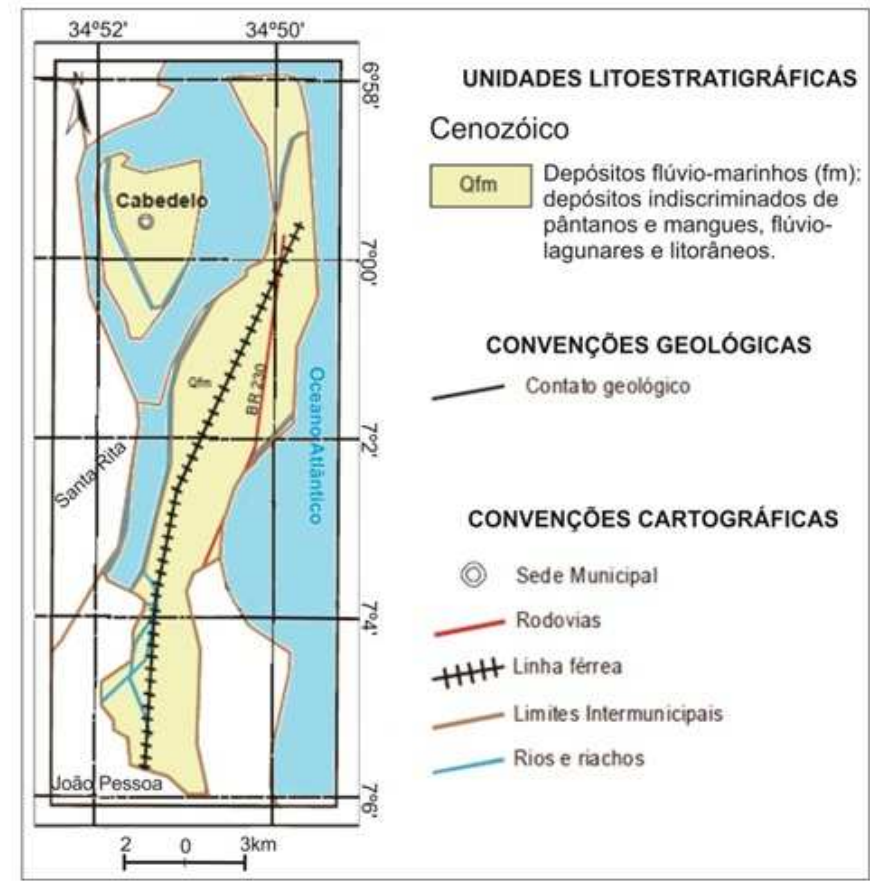

Figura 2 - Mapa geológico do município de Cabedelo. Fonte: Adaptado de CPRM (2005).

Neste estudo escolheu-se trabalhar com a unidade geológica “Depósitos Quaternários inconsolidados" como principal morfoestrutura, que é apresentada no mapa geomorfológico elaborado (Figura 4), na qual estão esculpidas as formas de relevo naturais e antropogênicas no município de Cabedelo.

Os cordões litorâneos de Cabedelo, provavelmente se formaram a partir de eventos pretéritos provocados pela variação do nível do mar no Holoceno onde o ápice marinho atingiu, aproximadamente, 5 metros acima do atual há 5.100 AP quando o mar recuou em estágios temporais deixando cordões litorâneos produzidos por eventos tempestivos (SUGUIO et al., 2005). 
Paralelamente aos cordões litorâneos de Cabedelo, em direção ao oceano, há ocorrência de recifes rochosos (beach rocks). Estes ambientes naturais extremamente dinâmicos, sobre os quais ocorre intensa atividade biogênica são de grande relevância para o equilíbrio dinâmico das praias, por ser uma barreira natural interceptando as ondas. De acordo com Muehe (2006) e Ab'Saber (2005), nos beach rocks podem se instalar colônias de corais e algas calcárias.

$\mathrm{Na}$ área de estudo, devido a disposição destes beach rocks forma-se em uma área específica o acúmulo de sedimentos biogênicos que ficam emersos na maré baixa. Este local é um dos principais atrativos turístico do município, sendo chamado de "Areia Vermelha".

\subsection{Contexto histórico - processo de ocupação e sua relação com a geomorfologia}

O processo de ocupação do município de Cabedelo iniciou-se desde a colonização brasileira, alterando as formas de relevo, e até mesmo as unidades geológicas mais superficiais. A alteração do relevo não se deu apenas na modificação das formas pré-existentes, mas também, na modificação dos processos geradores das formas de relevo. As primeiras unidades geomorfológicas a serem alteradas por ação antropogênica no município de Cabedelo foram as planícies interdiais às margens do Rio Paraíba, porta de entrada dos europeus nos tempos da colonização, por se tratar de uma área abrigada do embate das ondas.

Segundo IBGE (2016), Cabedelo é o segundo núcleo de colonização do estado da Paraíba. Seu nome significa "pequeno cabo" formado devido à acumulação de areia na foz de um rio. Em 1585, Martim Leitão deu início à colonização do local, que posteriormente originaria o povoado de Cabedelo.

Data do fim do século XVI a construção do Forte Velho e da Fortaleza de Santa Catarina, na planície do Rio Paraíba, que na época dos assédios dos piratas franceses e da invasão holandesa, serviram de palco a vários combates. Arrasada diversas vezes, essa fortaleza foi reconstruída outras tantas.

O primeiro trecho da estrada de ferro só veio a ser construído em 1886, ligando o porto de Cabedelo a João Pessoa - capital do estado. Esta construção foi uma das primeiras 
alterações do relevo, pois houve a necessidade de construção de aterros para elevar os trilhos deixando-os fora das áreas de inundação.

\section{Procedimentos Metodológicos e Técnicos}

A metodologia fundamentou-se na proposta de Libault (1971) baseada no levantamento de dados pertinentes ao trabalho (pesquisa bibliográfica, imagens de satélite, registros fotográficos e mapas) por meio dos quais se realizaram as comparações das informações obtidas na literatura e em campo, que foram significativas ao desenvolvimento do trabalho.

Os primeiros materiais utilizados foram as cartas topográficas de João Pessoa e Cabedelo produzidas pela SUDENE (1974), de escala 1:25.000 e curvas de nível com equidistância de 10 metros, que forneceram dados de grande precisão topográfica da área. Ressaltando que as cartas foram elaboradas mediante o método fotogramétrico de triangulação de área com apoio de técnicos no terreno para traçar numerosos pontos altimétricos. A partir da junção destas cartas e posterior recorte da área que abrange o município de Cabedelo, as curvas de nível foram vetorizadas e os dados vetoriais estiveram disponíveis em ambiente SIG para auxílio das análises geomorfológicas e produção dos demais produtos cartográficos.

O software SPRING 5.4.3 foi utilizado para vetorização e junção das cartas topográficas, bem como para tratamento e análise dos vetores e geração do mapa geomorfológico, auxiliando na visualização primária, em meio digital, dos compartimentos geomorfológicos presentes na área, que foram posteriormente aferidos em campo. Os programas TrackMaker Free e MapSource também foram utilizados, sendo estes responsáveis pela importação dos dados de GPS coletados em campo.

Para geração do mapa geomorfológico foi utilizada a metodologia de Ross (1992), com adaptações à realidade geomorfológica da área. Tal metodologia propõe uma classificação geomorfológica em seis níveis taxonômicos, que são:

10 Táxon: Unidade morfoestrutural - são as estruturas geológicas mais abrangentes;

2o Táxon: Unidades morfoesculturais - são as formas resultantes da ação dos elementos morfogenéticos sobre as morfoestruturas; 
30 Táxon: Padrões e formas do relevo semelhantes - refere-se a um conjunto de formas de relevo em um mesmo padrão;

40 Táxon: Tipos de forma de relevo - é o tipo de forma individualizada presente em um dado padrão de formas semelhantes;

50 Táxon: Setores das vertentes - são as formas individualizadas do relevo, cuja forma pode ser convexa, retilínea ou côncava;

6o Táxon: Pequenas formas de relevo - aquelas resultantes de processos atuais, naturais e antrópicos.

Para um melhor entendimento de todo o processo que deve ser feio para a elaboração do mapa geomorfológico, serão descritos a seguir alguns passos:

10 passo: para a determinação da morfoestrutura, é necessário ter em mãos as informações acerca da composição litológica da área em questão, como por exemplo, o mapa geológico da área e trabalhos de campo complementares. Em Cabedelo, foi estabelecido apenas um domínio: Depósitos quaternários inconsolidados.

2a passo: determinação da morfoescultura das grandes formas de relevo que predominam na área. Para a região compreendida pelo município de Cabedelo, foram definidas duas morfoesculturas: Planícies e Terraços da Paraíba.

30 passo: determinação dos padrões de forma do relevo. Para determinação desse táxon, pode ser utilizada a imagem em MDE em ambiente SIG, além de imagens de satélite e trabalhos de campo, onde se podem visualizar os padrões de forma que o relevo apresenta, desde as formas de denudação como também as de acumulação. Em Cabedelo foram estabelecidos os padrões: Atm - Formas de Acumulação de Terraços Marinhos; Apm Formas de Acumulação de Planícies Marinhas; e Api - Formas de Acumulação de Planícies Interdiais. Não foram encontrados padrões de formas denudacionais.

40 passo: determinação dos tipos de forma de relevo, que são calculados através do índice de dissecação do relevo. Neste trabalho, o índice de dissecação não pôde ser calculado, devido à realidade geomorfológica da área, que se trata de terreno de planícies e terraços com formas em níveis de dissecação irrisórios e inexistentes. 
5o passo: consiste na análise de vertentes, onde a construção de perfis topográficos da área pode ser utilizada. Porém, devido ao relevo aplainado da área, não foram elaborados perfis topográficos nem analisado o 5 ํ táxon.

60 passo: determinação das formas presentes no sexto táxon. Para identificar e mapear as formas de relevo atuais naturais e antropogênicas pode-se utilizar imagem de satélite, fotografias aéreas, e principalmente dados obtidos em campo. As formas foram identificadas e depois plotadas com o auxílio de um GPS no mapa geomorfológico. Algumas das formas encontradas no município foram: formas relacionadas à erosão costeira; minas inativas de extração de areia; depósitos tecnogênicos; e forte alteração da planície às margens do Rio Paraíba por atividades antropogênicas.

\section{Resultados e discussões}

\subsection{A cidade}

O município de Cabedelo contempla a única cidade portuária do estado da Paraíba. O Porto de Cabedelo representa espaço de grande relevância para o fluxo comercial de entrada e saída de mercadorias. Outra importante rota de fluxo comercial presente no município é a BR-230, que se inicia em Cabedelo, também considerada principal rodovia da Paraíba e uma das maiores do Brasil, também conhecida como Transamazônica.

O espaço urbano do município de Cabedelo encontra-se subdivido em 24 bairros (Tabela 1), cujo uso e ocupação do solo estão diretamente atrelados às peculiaridades físico-ambientais predominantes sobre as quais ocorrem processos antropogeomorfológicos distintos.

A concentração urbana se dá predominantemente em bairros mais próximos à orla, sendo também estes bairros mais densamente povoados, apresentando, desta forma, grandes influências nos processos geomorfológicos locais, especialmente àqueles referentes à geomorfologia costeira. A ilha da Restinga, que faz parte do município de Cabedelo não apresenta urbanização, sendo uma área preservada em suas características naturais. As regiões das planícies interdiais do Rio Paraíba são menos urbanizadas, exceto nos bairros de 
Renascer, na praia de Jacaré e nas proximidades do Porto e Forte Santa Catarina, onde se encontram ocupações que avançam até margem do rio (Figura 3).

\begin{tabular}{l|l|l|l|l|l}
\hline No & BAIRRO & ÁREA (ha) & No & BAIRRO & ÁREA (ha) \\
\hline 1 & Amazonas Park & 266,29 & 13 & Monte Castelo & 22.65 \\
\hline 2 & Areia Dourada & 29,62 & 14 & Morada Nova & 27,15 \\
\hline 3 & Camalaú & 45,17 & 15 & Parque Esperança & 172,73 \\
\hline 4 & Camboinha & 78,94 & 16 & Parque Verde & 32,54 \\
\hline 5 & Centro & 51,35 & 17 & Poço & 87,99 \\
\hline 6 & Formosa & 18,08 & 18 & Ponta de Campina & 122,21 \\
\hline 7 & Intermares & 199,71 & 19 & Ponta de Matos & 58,47 \\
\hline 8 & Jacaré & 140.56 & 20 & Portal do Poço & 126,71 \\
\hline 9 & Jardim América & 57,49 & 21 & Recanto do Poço & 325,98 \\
\hline 10 & Jardim Brasília & 27,40 & 22 & Renascer & 120,97 \\
\hline 11 & Jardim Camboinha & 177,20 & 23 & Salinas & 84,68 \\
\hline 12 & Jardim Manguinhos & 100,70 & 24 & Santa Catarina & 58.11 \\
\hline
\end{tabular}

Tabela 1 - Bairros do município de Cabedelo - PB.

Fonte: http://www.cabedelo.pb.gov.br/arquivos/bairros/Mapa_Geral_Todos_os_Bairros.pdf http://www.cabedelo.pb.gov.br/cidade_bairros_oficiais.asp.

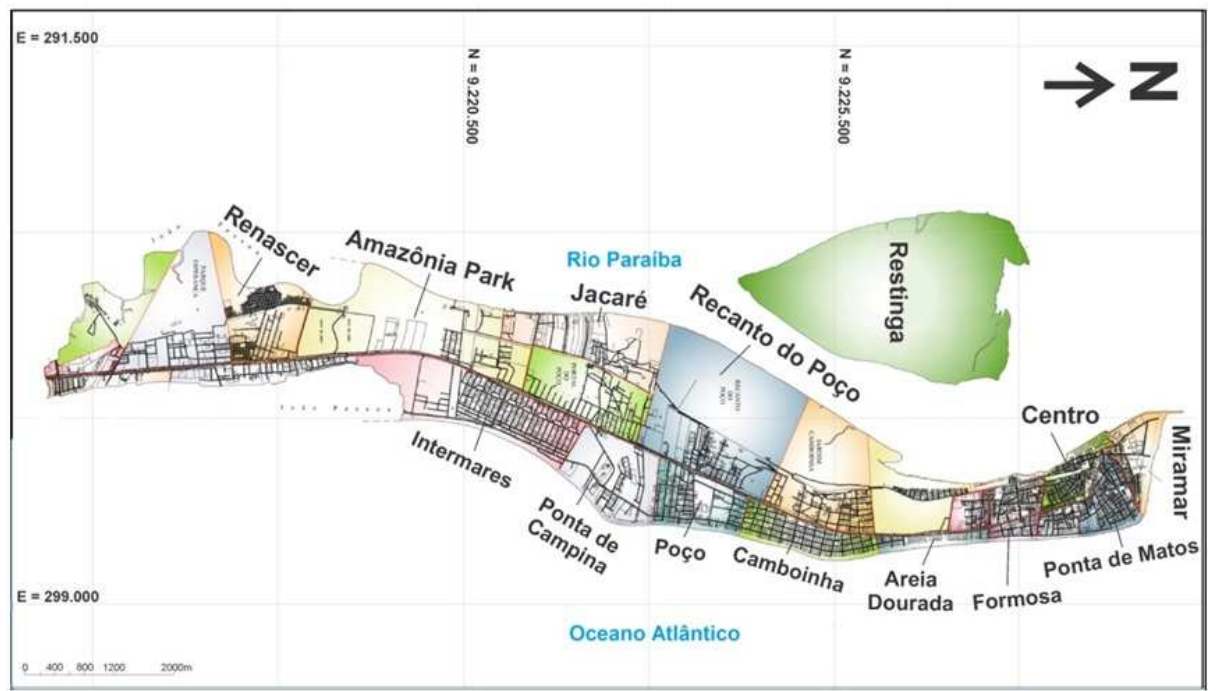

Figura 3 - Mapa de bairros do município de Cabedelo - PB. Fonte:

http://www.cabedelo.pb.gov.br/arquivos/bairros/Mapa_Geral_Todos_os_Bairros.pdf http://www.cabedelo.pb.gov.br/cidade_bairros_oficiais.asp.

Conforme supracitado, as características naturais atreladas à presença da rodovia BR 230 e da linha ferroviária foram importantes para o padrão de assentamento predominante na região, fato que se refletiu diretamente no valor comercial das terras em seu entorno. 
Observam-se em diferentes escalas, infraestruturas urbanas que têm provocado alteração significativa no relevo e processos geomorfológicos.

Dentre as atividades antrópicas modificadoras do relevo apresentam-se na área 0 extrativismo mineral e animal (coleta de mariscos e descarte das carapaças); aterros na planície interdial e costeira; além das construções inadequadas em áreas de mangue e planíce do rio, visando à exploração e expansão de áreas residenciais e comerciais.

\subsection{Geomorfologia e formas antropogênicas}

As formas de relevo encontradas no município de Cabedelo são apontadas no mapa geomorfológico (Figura 4). Neste mapa são destacadas as formas relacionadas ao 3ㅇ e ao 6으 táxon, que são os padrões de forma de relevo e as formas atuais naturais e antropogênicas, respectivamente.

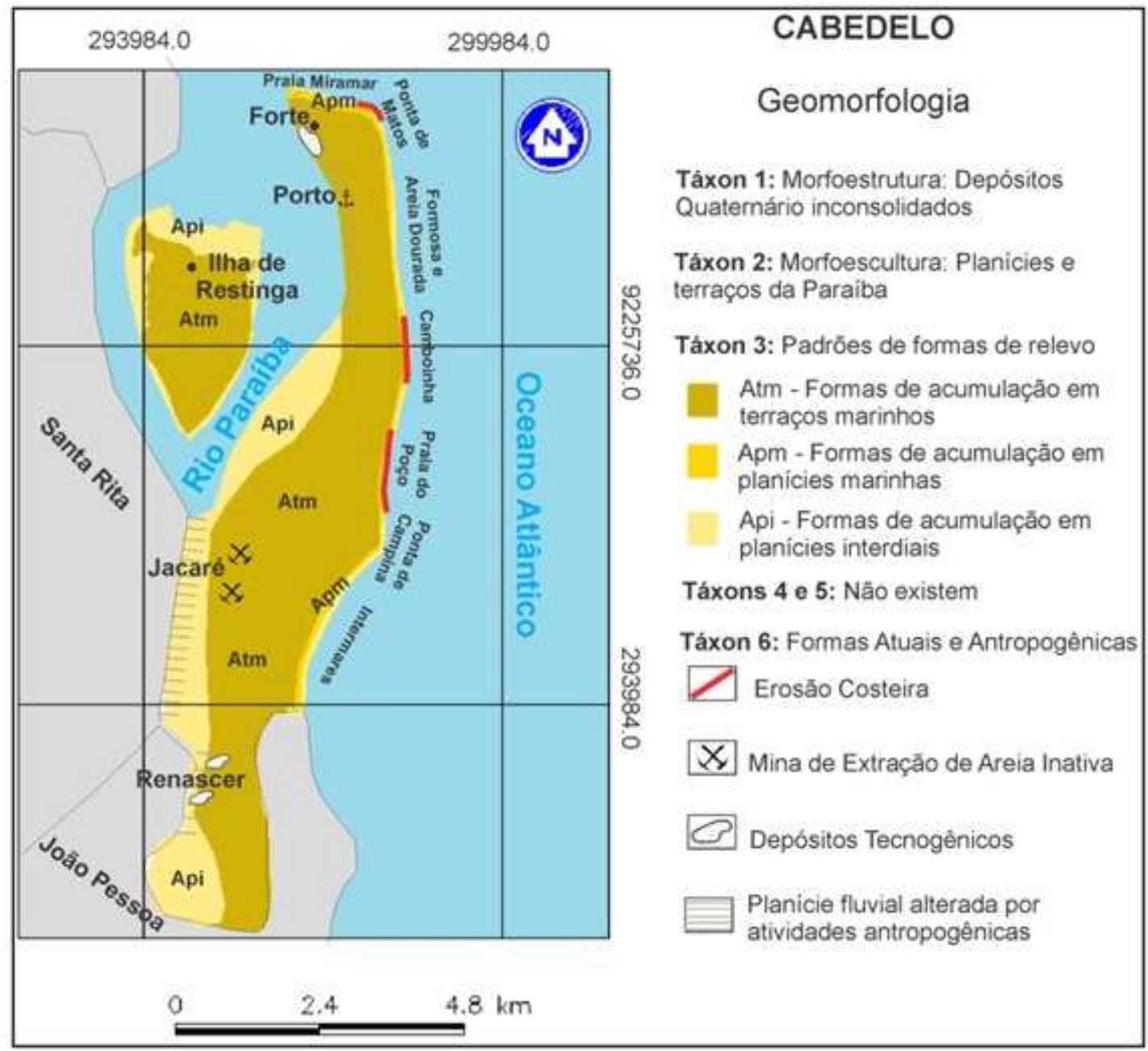

Figura 4 - Mapa geomorfológico do município de Cabedelo - Paraíba. 
Sobre as morfoesculturas observam-se três principais padrões de formas de relevo, que são: Atm - Formas de Acumulação em Terraços Marinhos, que ocupam a maior parte da área com 22,42 km²; Apm - Formas de Acumulação em Planícies Marinhas que se dispõem em toda faixa de praia e ocupam 0,89 km²; e Api - Formas de Acumulação em Planícies Interdiais, que são as áreas constantemente inundadas em períodos de maré alta, abrangendo $8,74 \mathrm{~km}^{2}$.

Os Táxons 4 e 5 não foram discriminados no mapa devido às configurações geomorfológicas específicas da área, por serem formas de relevo amplamente planas, com baixas cotas de altimetria e baixas declividades. Esses táxons são mapeados em áreas com relevo dissecado, como planaltos, cadeias montanhosas etc.

O sexto táxon é expresso no mapa como uma das informações mais importantes para este trabalho, pois neste táxon estão identificadas e mapeadas as formas de origem antropogênicas, que são formas consideradas atuais. No mapa, pode-se observar a presença de erosão costeira de ordem natural, porém acelerada pelo avanço de construções antrópicas à beira mar. As áreas mais afetadas pela erosão são as que apresentam construções na faixa de praia, como na Praia do Poço (Figura 4).

Além disso, foram mapeados depósitos tecnogênicos atuais que serão descritos a seguir, juntamente com as formas resultantes de atividades de mineração, que são antigas minas de extração de areia, hoje inativas, porém presentes em formas denudacionais negativas geradas por ação humana nas quais afloram água do lençol freático em seu interior. Não se pode deixar de notar a intensa modificação da planície interdial nas margens do Rio Paraíba, que também foi mapeada e é ponto de análise no presente artigo (Figura 4).

\subsection{Formas antropogênicas em Terraços Marinhos}

Nos terraços marinhos, indicados no mapa (Figura 4), algumas formas antropogênicas estão dispostas, como os depósitos tecnogênicos úrbicos, que são os que Peloggia (1998) define como detritos urbanos, materiais terrosos com artefatos manufaturados como tijolos, vidro, concreto etc. Também há formas resultantes da atividade econômica de mineração que 
ocorreu anteriormente, e que hoje são minas inativas com formas erosivas antropogênicas, nas quais se acumula água que aflora do lençol freático.

Os depósitos tecnogênicos encontrados na área de terraços marinhos estão localizados, principalmente, em dois bairros: Renascer e Centro (Ver figuras 3 e 4). No bairro do Renascer, sobre os terraços marinhos que formam os cordões litorâneos de Cabedelo, há uma intensa atividade antropogênica de aterramento da área utilizando materiais úrbicos. Mesmo sendo um ambiente de morfologia plana, a medida visa estabilizar o terreno, criando um ambiente mais propicio à implantação de prédios residenciais, galpões comerciais, arruamentos etc. Os depósitos úrbicos nesta área chegam a atingir camadas verticais com mais de dois metros (Figura 5).

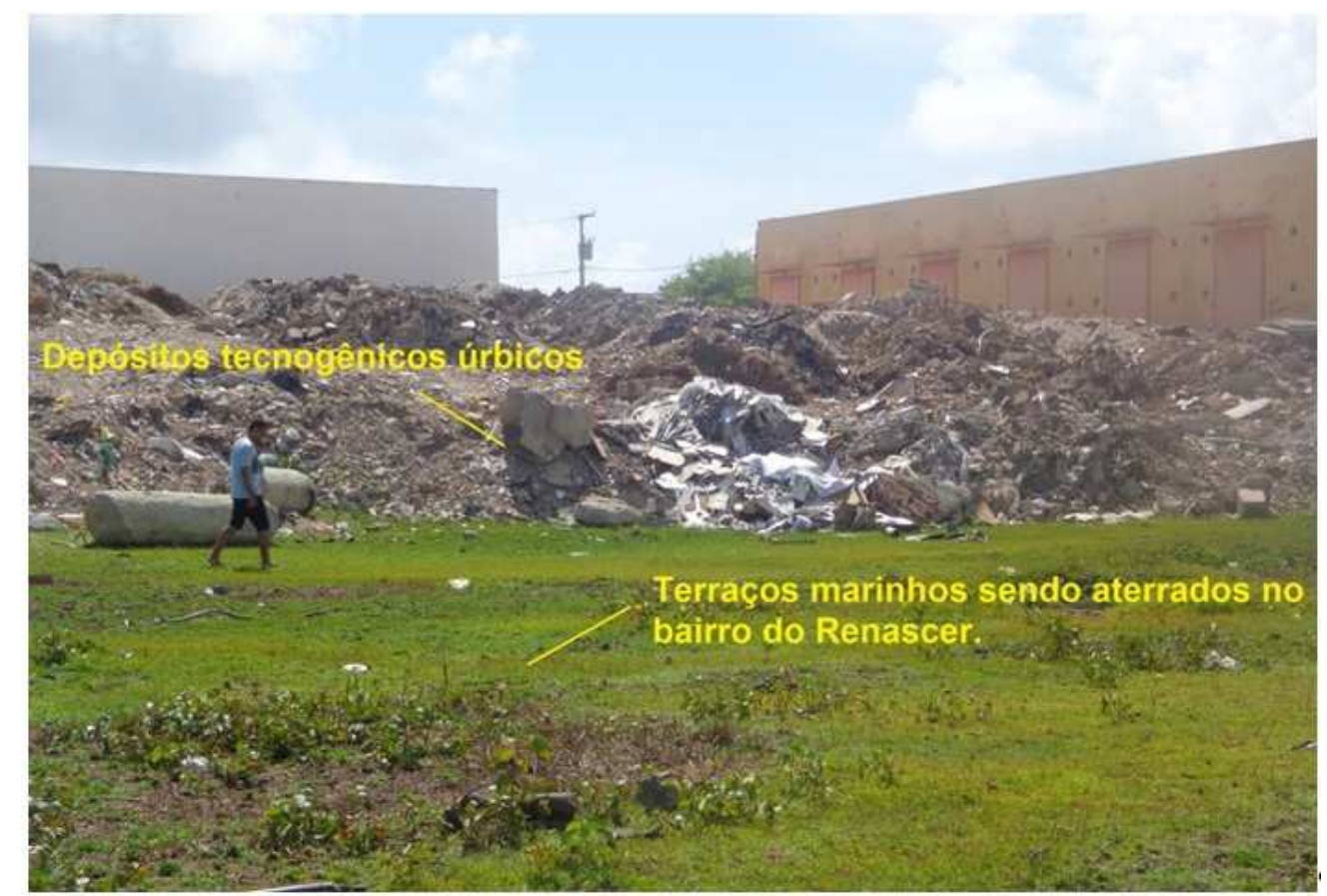

Figura 5 - Depósitos tecnogênicos úrbicos no bairro do Renascer, Cabedelo - PB.

Os depósitos tecnogênicos úrbicos são importantes tanto para a Geomorfologia, pois está sendo modificada a forma, topografia e altitude da superfície do relevo, como também para a Geologia, pois em longo prazo estes depósitos serão incorporados às formações geológicas da área, podendo gerar rochas sedimentares antropogênicas, em decorrência da quantidade de material de origem antrópica depositado. 
Assim, os aterros sobre os terraços marinhos nesta área trazem profunda modificação geológica e geomorfológica, além de interferir nos sistemas de infiltração e escoamento de águas pluviais, e na carga de sedimentos que estão sendo transportados para o Rio Paraíba.

No bairro do Centro, nas proximidades do Forte de Cabedelo, encontra-se outro depósito antropogênico em forma de dique ou barreira, que também pode ser considerado como um terraço antropogênico, construído para impedir ação da erosão no estuário do Rio Paraíba. Além desta finalidade, esse dique avança em direção ao mar formando um "guia corrente" com o propósito de impedir a ação de ondas na entrada do porto e o assoreamento do canal. Este dique foi construído através do depósito de blocos de rochas cristalinas e possui uma extensão de aproximadamente 1.055 m (Figura 6).

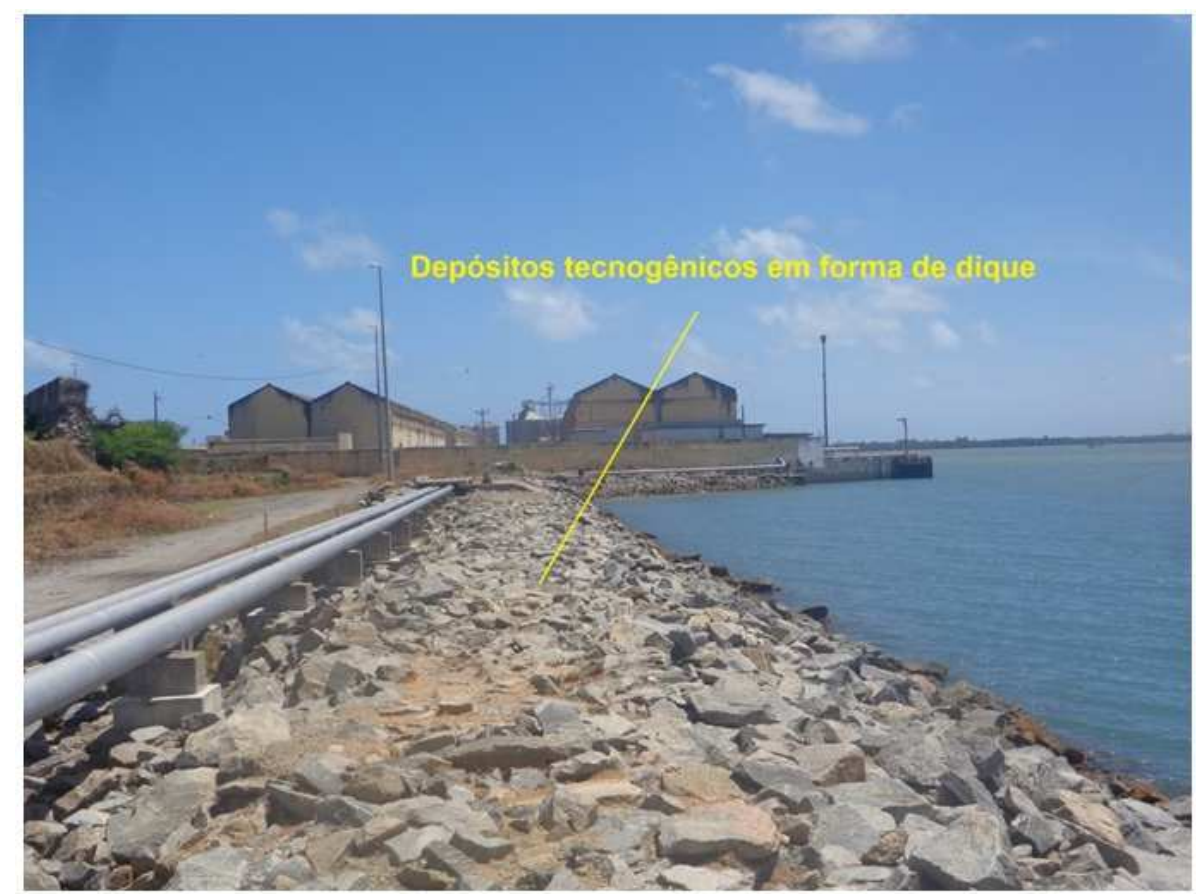

Figura 6 - Depósito tecnogênico em forma de dique, para proteção da erosão no estuário do Rio Paraíba.

Este tipo de depósito é diferenciado, pois é composto por materiais rochosos originados de processos geológicos naturais e não por materiais antropogênicos, assim, se configura depósito tecnogênico pelo fato de terem sido colocados sobre os terraços marinhos, modificando os processos naturais da área em virtude da modificação ambiental ocasionada. Observa-se também que a barreira formada pelo dique interferiu significativamente na dinâmica costeira local, aumentando o aporte de sedimentos na praia 
de Miramar e Ponta de Matos, ao norte, nas quais se configuram faces de praias mais largas do que o observado em outras praias do município. Típico processo de progradação da linha de costa devido à interferência antrópica.

Em relação às formas resultantes da mineração no município de Cabedelo, encontram-se no bairro do Jacaré, antigas minas de extração de areia, que hoje estão inativas e uma delas está sendo aterrada. As minas compõem extensas formas erosivas denudacionais de origem antropogênica, que por atingirem o lençol freático, atualmente formam lagoas com dimensões de até 470 m de extensão (Figura 7).

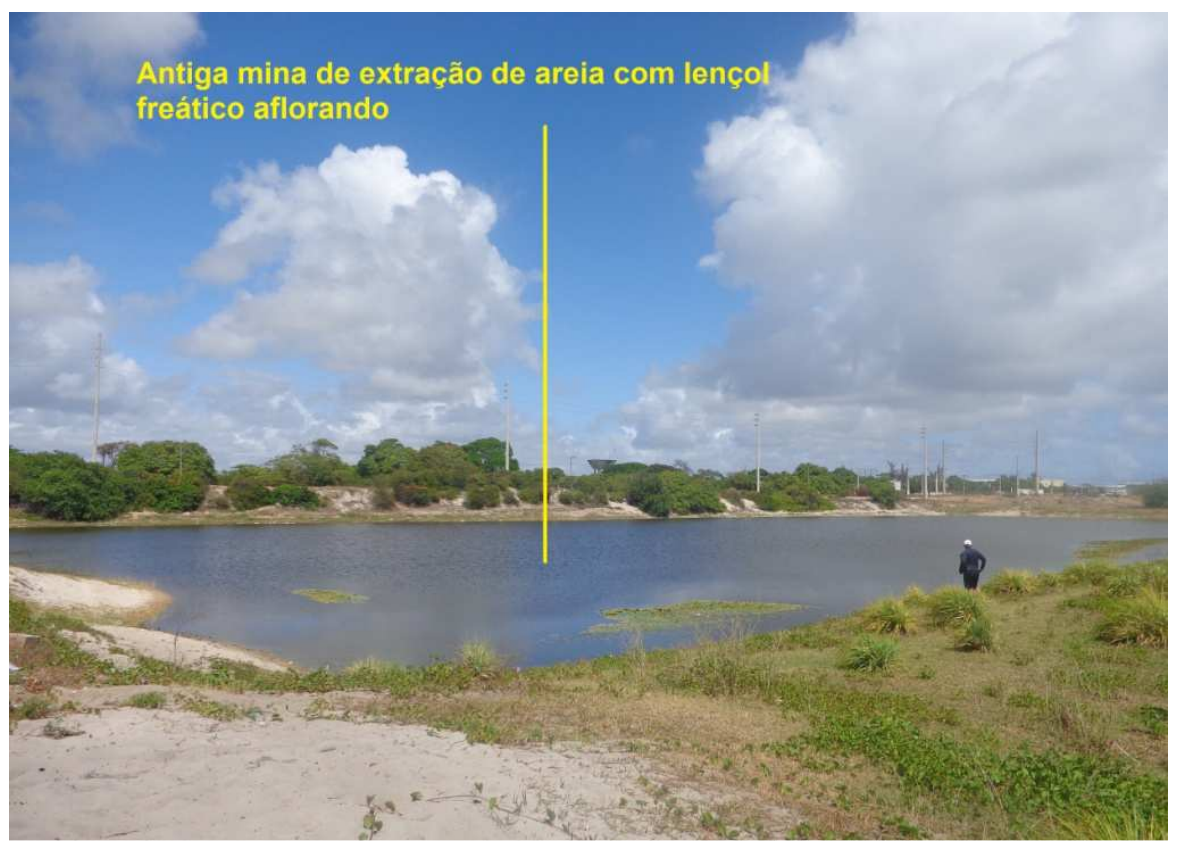

Figura 7 - Mina inativa de extração de areia no bairro de Jacaré, Cabedelo - PB.

Com a antiga atividade de mineração, modificaram-se substancialmente os terraços marinhos neste setor. Inclusive, mesmo após cessar o desenvolvimento desta atividade, ainda permaneceram tais mudanças e formas erosivas de grandes dimensões. Isso ocorre comumente em áreas de mineração, e, geralmente, devem ser elaborados planos de recuperação destas áreas e reparo pelos danos ambientais causados pela exploração do recurso.

Não se observa na mina inativa (Figura 7) nenhum indício de projetos para recuperação da área, pelo contrário, após afloramento do lençol freático, as antigas minas foram incorporadas à paisagem como "As Lagoas do Jacaré". Em uma das minas observadas, após o fim das atividades está sendo desenvolvido um trabalho de dragagem da água no fundo 
da mina e aterramento da área para dar lugar aos novos prédios que estão se instalando na região (Figura 8).

Entretanto, deve-se ter em conta que, a construção nessa área, mesmo aterrada, é de forte risco geológico-geomorfológico, e um estudo geotécnico deverá ser executado, uma vez que os terrenos compostos por depósitos tecnogênicos configuram ambientes de forte suscetibilidade a acomodações dos materiais depositados.

\section{Água sendo dragada na antiga mina}

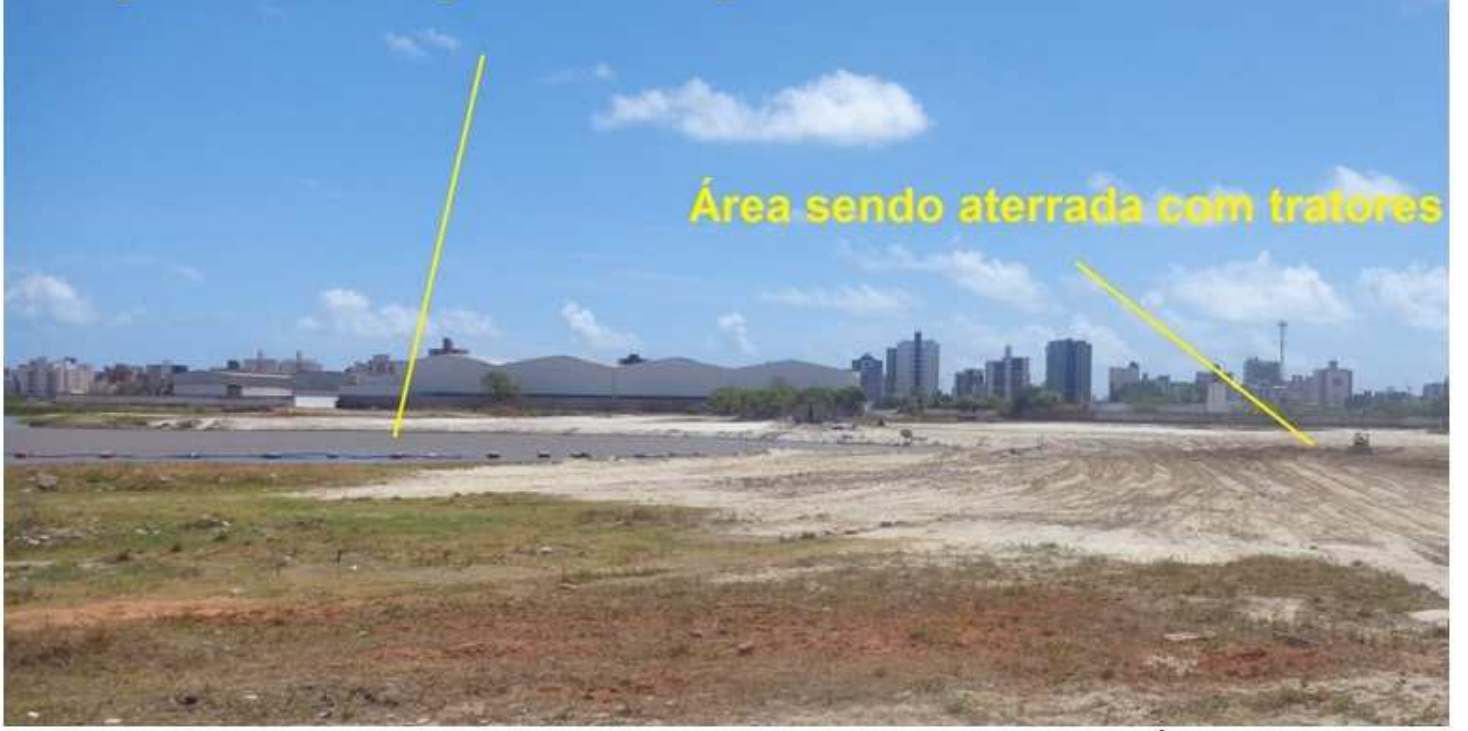

Figura 8 - Mina inativa de extração de areia em Jacaré, Cabedelo - PB. Água sendo dragada e área sendo aterrada.

\subsection{Formas antropogênicas na planície interdial do Rio Paraíba}

A planície interdial do Rio Paraíba, nesta área, foi intensamente modificada ao longo do tempo pelas atividades antropogênicas. Inicialmente pela construção do porto onde foi efetuada uma dragagem para aprofundamento do calado. Posteriormente, as comunidades ribeirinhas que se instalaram na planície interdial utilizaram do ambiente de mangue (mangal) para desenvolver atividades econômicas e de sobrevivência no local. Assim, as suas relações sociais e econômicas estão intrinsecamente ligadas à geomorfologia e demais características ambientais da área.

Dois grandes exemplos da utilização e transformação da planície interdial do Rio Paraíba nesta área é a praia de Jacaré, que na verdade é parte do estuário do Rio Paraíba; e o bairro 
do Renascer, onde a ocupação da planície chega até a margem do rio com casas construídas pela comunidade ribeirinha e desenvolvimento de atividades de extrativismo animal na região de mangue.

No bairro de Jacaré o que potencializa as transformações e alterações da planície interdial do Rio Paraíba são as atividades turísticas e culturais (Figura 9). Foram construídas áreas de lazer sobre a planície, bem como trapiches para saída de pequenas embarcações.

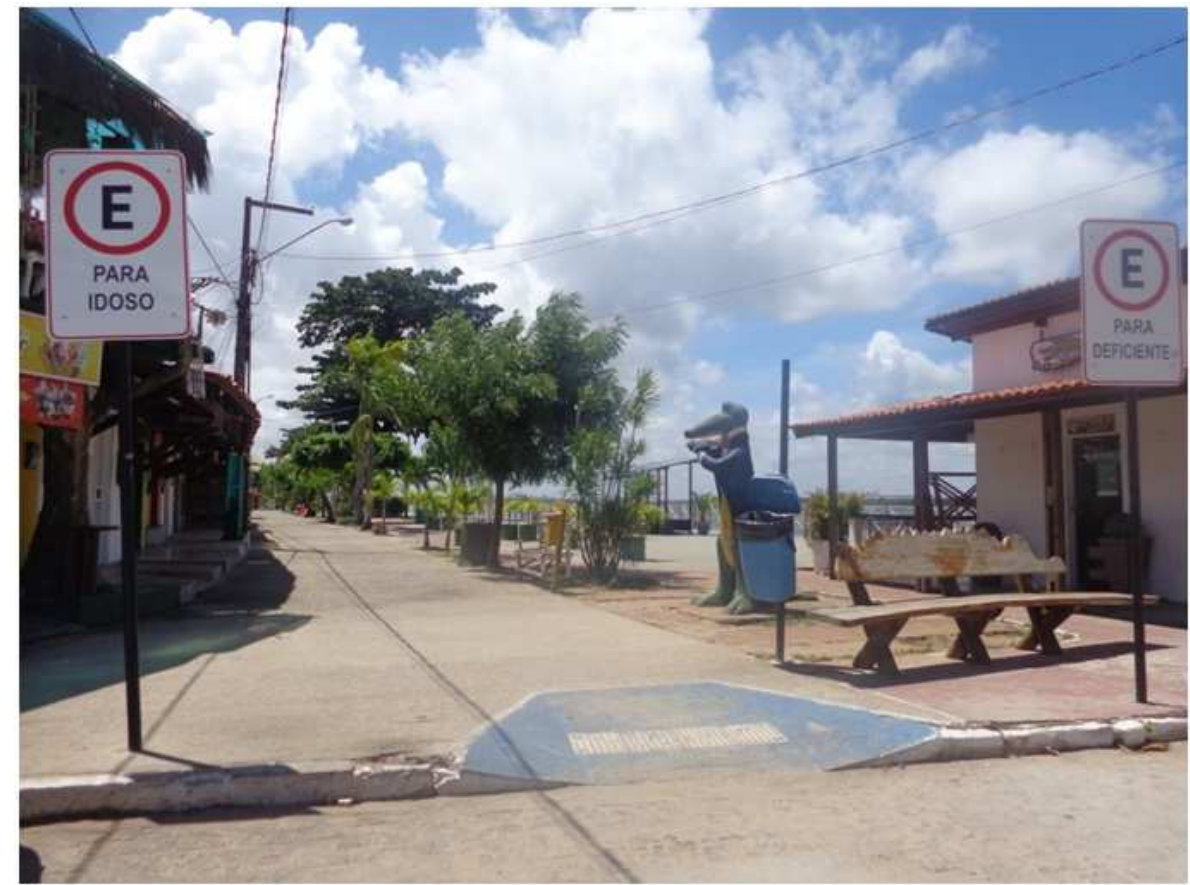

Figura 9 - Área de lazer sobre a planície interdial do Rio Paraíba no bairro de Jacaré.

A planície, neste trecho, está completamente descaracterizada de seus aspectos naturais, assim como em seus processos geomorfológicos. Os sedimentos finos que compunham a planície foram, em grande parte, substituídos por gabiões de granito (Figura 10). O aporte de sedimentos, erosão e deposição, nesta área do rio, mudaram em decorrência disto. 


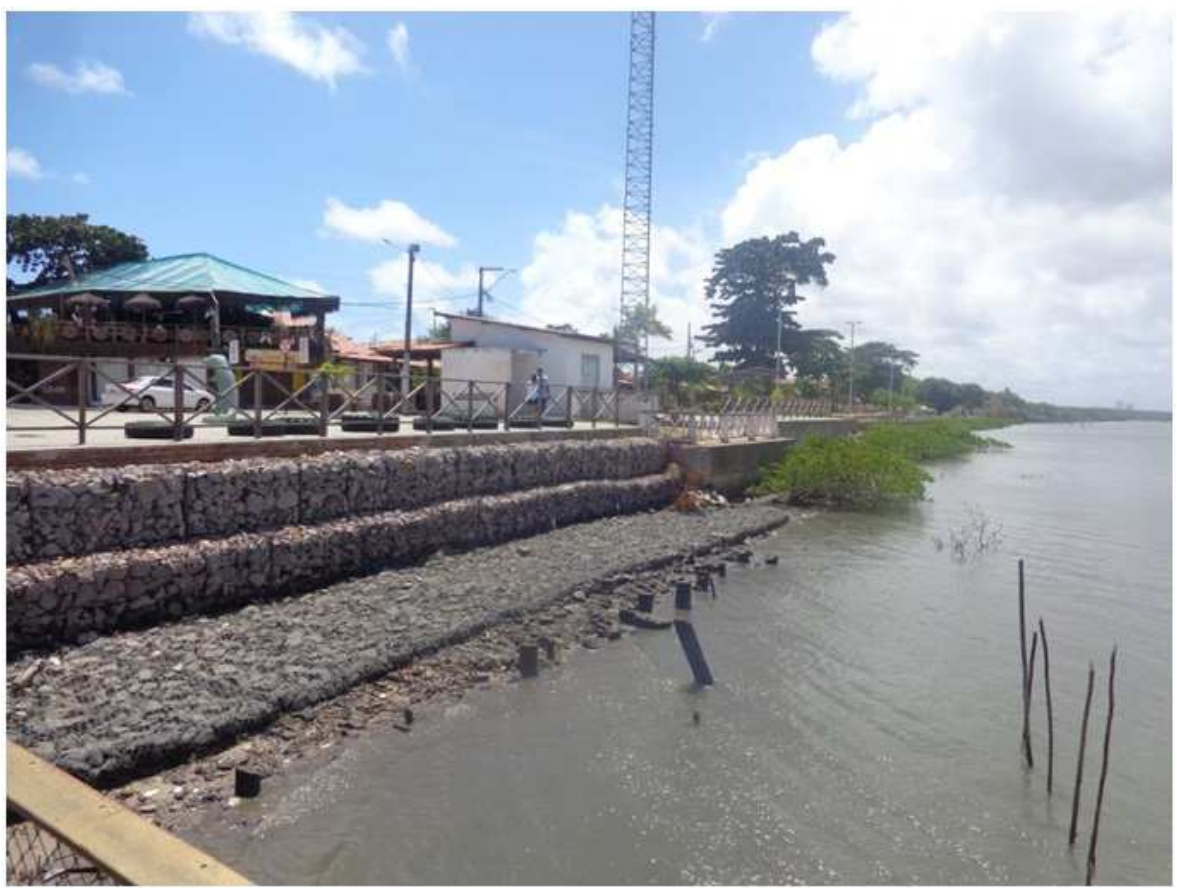

Figura 10 - Gabiões de granito descaracterizando completamente a planície interdial no Bairro de Jacaré.

No bairro do Renascer, como dito anteriormente, as atividades de extrativismo animal são desenvolvidas com intensidade e por isso há a formação de depósitos tecnogênicos constituídos por restos de conchas e carapaças de animais constituidas de carbonato de cálcio (Figura 11).

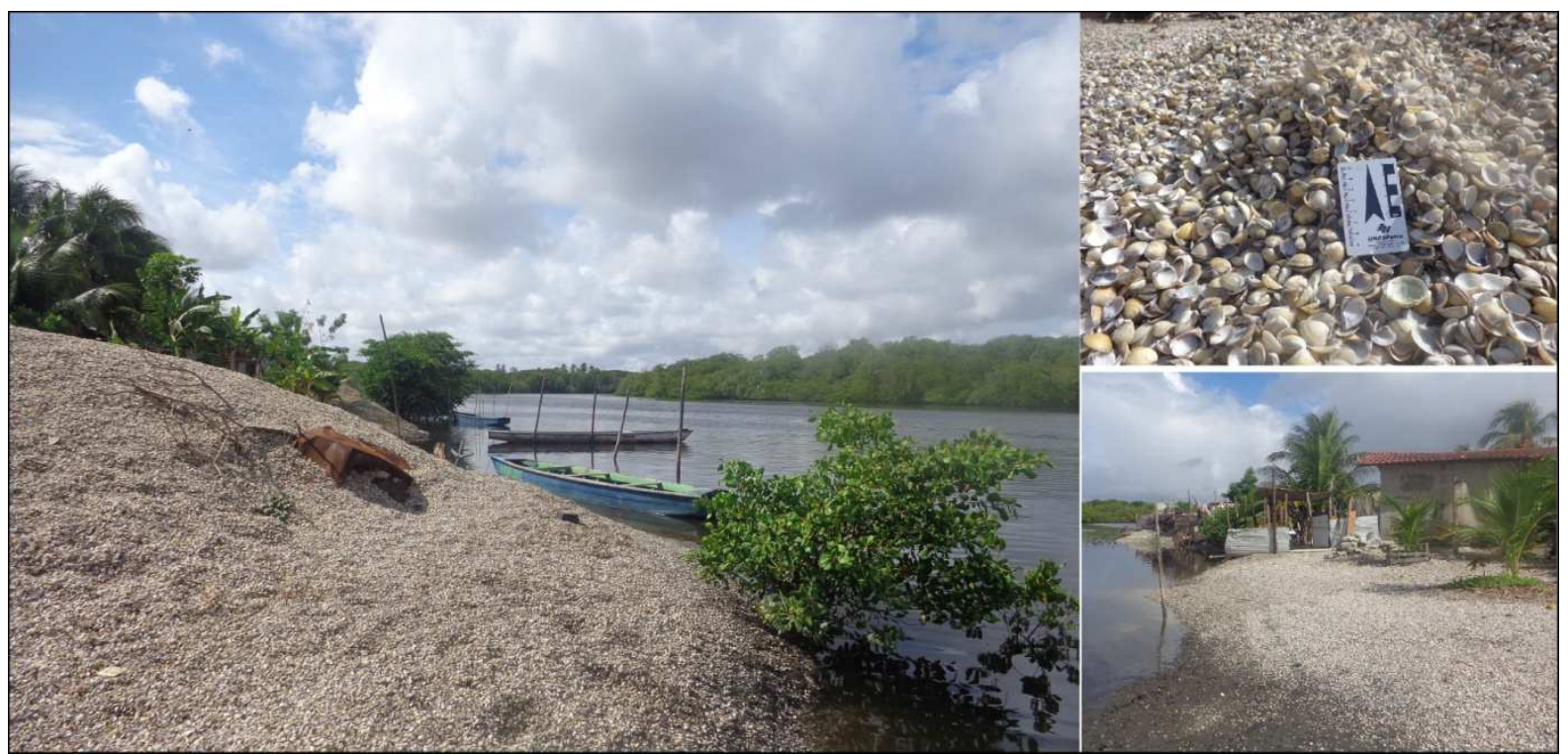

Figura 11 - Depósitos tecnogênicos decorrentes de atividades de extrativismo nas margens do rio Paraíba no bairro do Renascer. 
A quantidade elevada deste material existente nestes depósitos lembra a formação dos antigos "Sambaquis", estudados atualmente por arqueólogos e que resultaram das atividades dos povos nativos que viveram na região litorânea antes da colonização (em Portugal designados por concheiros). Sambaquis são definidos como elevações de formas arredondadas, que em algumas regiões do Brasil chegam a ter mais de $30 \mathrm{~m}$ de altura, com amontoados de conchas e carapaças provindas do extrativismo praticado por estes povos, sem fins econômicos, e sim para sobrevivência e como modo de vida (GASPAR, 2000).

Porém, os depósitos tecnogênicos do Renascer provêm de atividades econômicas de extrativismo e não atende a nenhuma das classificações de tipos de depósitos antropogênicos citados em Peloggia (1998).

Sendo assim, cabe uma nova classificação para englobar este tipo de depósito presente no bairro do Renascer, cuja denominação atribuí-se ao termo de origem, ou seja, depósitos provenientes de atividades extrativistas. Neste caso, o rejeito extrativista pode alterar a morfologia da área submetida à exploração de determinado recurso natural (animal, mineral ou vegetal) sem a devida preocupação com manutenção das feições e dinâmica natural do espaço submetido à exploração, podendo provocar impactos diretos como o assoreamento e alteração de margens dos rios, alteração no perfil dos solos etc.

\subsection{Ocupação da zona costeira - A erosão costeira por causas antropogênicas}

Os ambientes costeiros são terrenos propícios à intensa especulação imobiliária e também são áreas turísticas, sobretudo em função dos atrativos de recreação que esses espaços oferecem. Nesta perspectiva, ressalta-se a relevância de se programar nestes ambientes ações adequadas de planejamento e conservação, visando mitigar os processos que provocam a degradação da paisagem (SOUZA \& FURRIER, 2005), haja vista que, por se constituírem faixas limítrofes entre a litosfera, hidrosfera e atmosfera, observam-se nestas regiões, intercâmbios contínuos de energia e matéria.

No caso das praias do município de Cabedelo, buscou-se averiguar a condição atual da orla no que tange os problemas comuns às zonas litorâneas, entre os quais se elencam: degradação da vegetação autóctone e ocupação irregular por infraestruturas de procedência civil (casas, bares, obras de contenção). Neste caso, tais características estão 
diretamente atreladas ao surgimento de ambientes que apresentam zonas de vulnerabilidade ambiental e danos provocados pela erosão costeira.

A planície marinha de Cabedelo bordeja os terraços marinhos sobre os quais ocorre exponencial expansão urbana. Ao todo são sete praias (vide Figura 4) que apresentam formas de uso e ocupação distintas, e por isso se observam respostas da dinâmica natural diretamente proporcional a estas características que revelam numa mesma região, praias com feições longitudinais estáveis e outras não.

A planície marinha nas praias observadas é relativamente estreita, com exceção das praias de Intermares e Miramar. Esta última, no entanto, tem como causa direta do engordamento da faixa praial a obra do dique de contenção construído no limite setentrional da área, mais precisamente na divisa entre o mar e a foz do rio Paraíba. Já nas praias de Ponta de Matos, Camboinha e do Poço, constataram-se trechos com fortes impactos provocados por erosão costeira, sobretudo, durante os eventos de marés de sizígia, atrelados às intervenções antropogênicas (Figura 12).
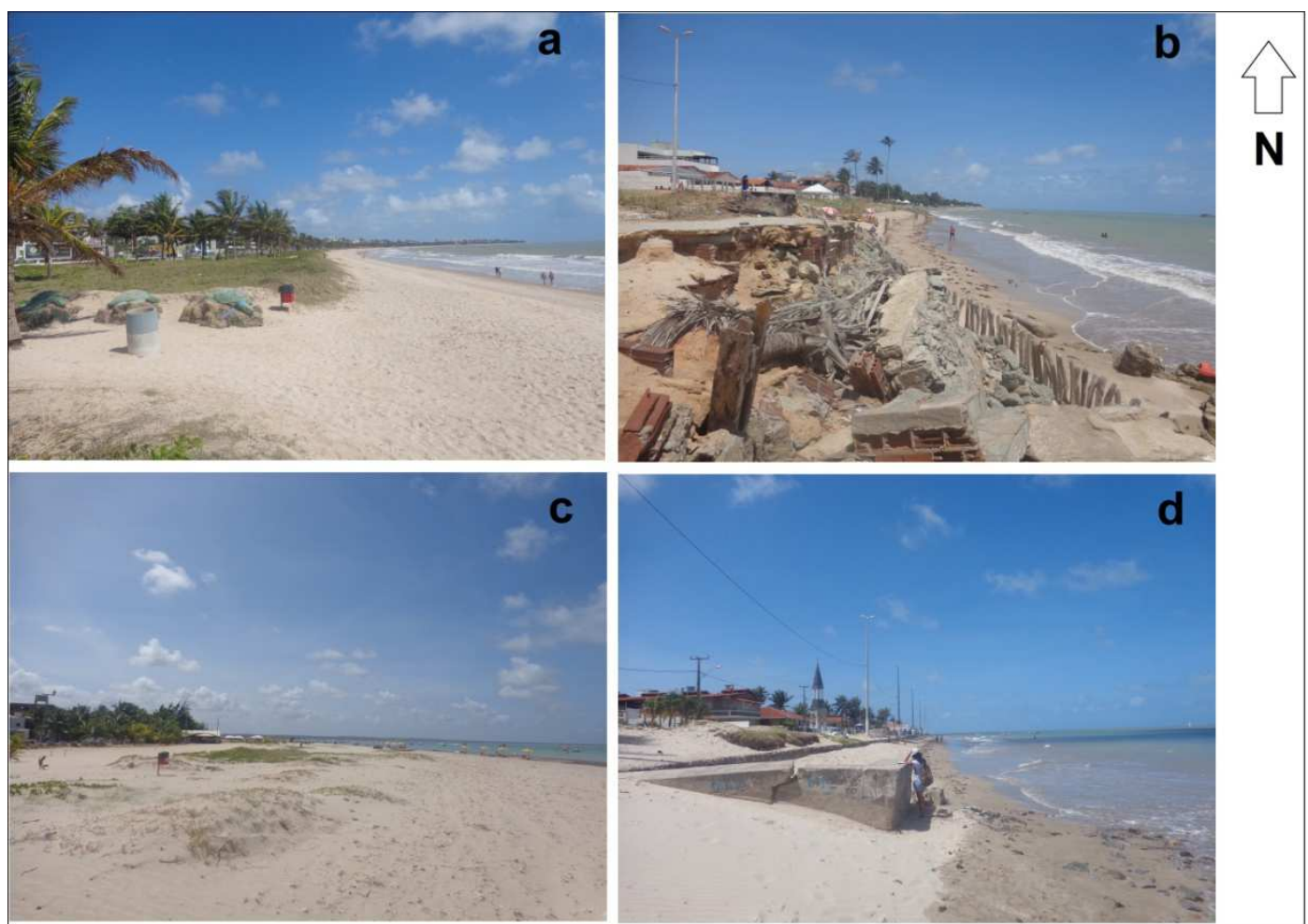

Figura 12 - a) Praia estável em Intermares; b) Erosão na praia do Poço; c) Praia estável em Miramar; d) Erosão na praia de Ponta de Matos. 
Nesta perspectiva, sobressai-se a importância de observância de Leis e planejamento técnico que estabeleçam um plano de gestão e ocupação das praias a partir dos parâmetros instituídos no âmbito do Plano Nacional de Gerenciamento Costeiro (PNGC) conforme disposto no Artigo 3o da referida lei "O PNGC deverá prever o zoneamento de usos e atividades na zona costeira e dar prioridade à conservação e proteção, entre outros" (BRASIL, 1988).

Outras premissas fundamentais para programar o padrão de ocupação das zonas costeiras devem ser extraídas da Lei no 6.938/1981 (Política Nacional do Meio Ambiente - PNMA), que prevê no artigo 20 a preservação, melhoria e recuperação da qualidade ambiental propícia à vida, visando assegurar, no país, condições ao desenvolvimento socioeconômico, aos interesses da segurança nacional e a proteção da dignidade da vida humana (BRASIL, 1981).

Nesta perspectiva, foram enfatizados os seguintes princípios que constam nos parágrafos regulamentadores da PNMA: (i) IV - proteção dos ecossistemas, com a preservação de áreas representativas; (ii) VII - acompanhamento do estado da qualidade ambiental; (iii) IX proteção de áreas ameaçadas de degradação; (iv) X - educação ambiental a todos os níveis do ensino, inclusive à educação da comunidade, objetivando capacitá-la para participação ativa na defesa do meio ambiente.

A implicação da forma como está sendo ocupada a orla do município estudado é a existência de praias estáveis e praias com degradação estética da paisagem provocada por erosão. Cabe destacar que, em ambos os casos, as praias se situam uma ao lado da outra; estão confinadas num mesmo arcabouço geológico sedimentar; faixa de pouca extensão e largura morfológica; e estão submetidas às mesmas condições meteorológicas e oceanográficas. Desta forma, as praias que apresentam danos provocados pela erosão costeira, têm como principal consequência a combinação da ação de processos naturais que se agravam devido às intervenções antrópicas em zonas que, se observada a legislação regulatória vigente, estão em situação de irregularidade. 


\section{Conclusões}

A urbanização e a constante ação antropogênica têm modificado intensamente as formas e processos geológicos e geomorfológicos naturais nos três padrões de formas de relevo presentes no município: formas de acumulação em terraços marinhos, formas de acumulação em planícies marinhas e formas de acumulação em planícies interdiais. Assim, novas feições atuais são criadas sob a influência da ação direta e/ou indireta do homem, e estruturas geomorfológicas antropogênicas são originadas, principalmente os depósitos tecnogênicos.

Tais modificações podem implicar no desequilíbrio do atual sistema ambiental, e gerar zonas de maior impacto no sistema tais como: erosão costeira, mudança na corrente litorânea, modificações nas drenagens, aterramento de planícies interdiais, intensificação do aporte sedimentar para o Rio Paraíba entre outros.

O mapeamento, a quantificação e a análise das formas antropogênicas são de fundamental importância para o planejamento ambiental e territorial, além de poder disciplinar futuros usos da terra, impedindo ou assessorado a ocupação sobre depósitos antropogênicos. Embora esta pesquisa tenha sido desenvolvida em um município pequeno, essa metodologia de caracterização e mapeamento de feições tecnogênicas pode ser estendida a outras áreas onde as modificações antropogênicas sobre o relevo sejam maiores e mais impactantes.

\section{Referências bibliográficas}

AB'SABER, A. N. Litoral do Brasil/Brazilian coast. São Paulo, Metalivros, 2005.

BASKIN, J. The ideology of Anthropocene? Melborne: Melborne Sustainable Society Istitute; The University of Melborne, MSSI Research Paper n.3, $2014 . \quad$ Disponível em: <http://sustainabledev.unimelb.edu.au/sites/default/files/docs/MSSI-ResearchPaper-3_Baskin_2014.pdf>. Acesso em 20 out. 2014;

BRASIL. Lei no 6.938, de 31 de agosto de 1981. Dispõe sobre a Política Nacional do Meio Ambiente, seus fins e mecanismos de formulação e aplicação, e dá outras providências. Diário Oficial da República Federativa do Brasil, Brasília, DF, 2 set. 1931. Disponível em: <http://www.planalto.gov.br/ccivil 03/leis/l6938.htm>. Acesso em: 22 set. 2012. 
BRASIL. Lei no 7.661, de 16 de maio de 1988. Institui o Plano Nacional de Gerenciamento Costeiro e dá outras providências. Diário Oficial da República Federativa do Brasil, Brasília, DF, 18 maio 1988. Disponível em: <http://www.planalto.gov.br/ccivil 03/leis/l7661.htm>. Acesso em: 22 set. 2012.

BRASIL. Ministério do Interior. Superintendência de Desenvolvimento do Nordeste. Folhas João Pessoa e Cabedelo. Recife: SUDENE, 1974. Escala 1:25.000.

CPRM - Serviço Geológico do Brasil. Projeto cadastro de fontes de abastecimento por água subterrânea. Diagnóstico do município de Cabedelo, estado da Paraíba/ Organizado [por] João de Castro Mascarenhas, Breno Augusto Beltrão, Luiz Carlos de Souza Junior, Franklin de Morais, Vanildo Almeida Mendes, Jorge Luiz, Fortunato de Miranda. Recife: CPRM/PRODEEM, 2005.

GASPAR, M. Sambaqui: arqueologia do litoral brasileiro. Rio de Janeiro: Jorge Zahar Ed. , 2000.

IBGE - Instituto Brasileiro de Geografia e Estatística. IBGE cidades - Cabedelo/PB. Disponível em: http:/www./cidades.ibge.gov.br/xtras/perfil.php?lang=\&codmun=250320\&search=| | infogr\%E1ficos:informa\%E7\%F5es-completas Acesso em 28/12/2016.

INPE - INSTITUTO NACIONAL DE PESQUISAS ESPACIAIS. Previsão do tempo para Cabedelo. Disponível em: http://www.cptec.inpe.br/cidades/prevOceanica/1056>. Acesso em 27/12/2016.

LIBAULT, A. Os quatro níveis da pesquisa geográfica. Métodos em Questão, São Paulo: Instituto de Geografia (USP), n. 1, p. 1-14, 1971.

MUEHE, D. (Org.). Erosão e progradação no litoral brasileiro. Brasília: MMA, 2006.

NIR, D. Man, a geomorphological agent: an introduction to anthropic geomorphology. Jerusalem, Ketem Pub. House, 1983.

PELOGgIA, A. U. G. Delineação e aprofundamento temático da Geologia do Tecnógeno do Município de São Paulo. 1996. 262 f. Tese (doutorado), Instituto de Geociências da USP, São Paulo, 1996.

PELOGGIA, A. U. G. A ação do homem enquanto ponto fundamental da geologia do Tecnógeno: proposição teórica básica e discussão acerca do caso do município de São Paulo. Revista Brasileira de Geociências, v. 27, p. 257 - 268, 1997.

PELOGGIA, A. U. G. O homem e o ambiente geológico: geologia, sociedade e ocupação urbana no município de São Paulo. São Paulo: Xamã, 1998. 270 p.

PELOGGIA, A. U. G. O Tecnógeno existe? In: CONGRESSO BRASILEIRO DE GEOLOGIA DE ENGENHARIA, São Pedro (SP). Anais... ABGE (CD-ROM), 1999. 13 p.

PELOGGIA, A. U. G. O problema estratigráfico dos depósitos tecnogênicos. In: CONGRESSO DA ASSOCIAÇÃO BRASILEIRA DE ESTUDOS DO QUATERNÁRIO, Recife (PE), Anais... Abequa, 2003.

PELOGGIA, A. U. G. A cidade, as vertentes e as várzeas: a transformação do relevo pela ação do homem no município de São Paulo. Revista do Departamento de Geografia (USP), São Paulo, v.16, p. 24 - 31, 2005.

PEloggiA, A. U. G.; OliveIRA, A. M. S.; OliVEIRA, A. A.; SILVA, E. C. N., NUNES, J. O. R. Technogenic geodiversity: a proposal on the classification of artificial ground. In: Revista Quaternary and Environmental Geosciences, Curitiba, v.5, n.1, p. 28-40, 2014 a. Disponível em: <

http://ojs.c3sl.ufpr.br/ojs2/index.php/abequa/article/view/34823>. Acesso em 20 out. 2014.

PELOGGIA, A. U. G.; SILVA, E. C. N.; NUNES, J. O. R. Technogenic landforms: conceptual framework and application to geomorphologic mapping of artificial ground and landscape as transformed by human geological action. In: Revista Quaternary and Environmental Geosciences, Curitiba, v.5, n.2, p. 28-40, 2014 b. Disponível em: <http://ojs.c3sl.ufpr.br/ojs2/index.php/abequa/article/view/34811>. Acesso em 20 out. 2014.

RODRIGUES, C. Morfologia original e morfologia antropogênica na definição de unidades espaciais de planejamento urbano: exemplo na metrópole paulista. Revista do Departamento de Geografia, v. 17, p. 101111,2005

ROSS, J. L. S. 1992. O registro dos fatos geomórficos e a questão da taxonomia do relevo. Revista do Departamento de Geografia. São Paulo, n. 6, 17-29. 
SILVA, E. C. N. Formação de depósitos tecnogênicos e relações com o uso e ocupação do solo no perímetro urbano de Presidente Prudente - SP. 2012. 183 f. Dissertação (Mestrado em Geografia). Faculdade de Ciência e Tecnologia, Universidade Estadual Paulista, Presidente Prudente.

SOUZA, A. S; FURRIER, M. Caracterização geomorfológica e ocupação antrópica de zonas costeiras: o caso da Ponta do Seixas, litoral da Paraíba - Brasil. Revista do Departamento de Geografia, São Paulo, v. 30, p. 166-178, dec. 2015. ISSN 2236-2878.

SUGUIO, K.; ÂNGULO, R. J; CARVALHO, A. M.; CORRÊA, I. C. S.; TOMAZELLI, L. J.; WILLWOCK, J. A. VITAL, H. Paleoníveis do mar e paleolinhas de costa. In: SOUZA, C. R.; SUGUIO, K.; OLIVEIRA, A. M. S.; DE OLIVEIRA, P. E. (Ed.). Quaternário do Brasil. Ribeirão Preto; Holos, Editora, 2005. P. 114-129.

SZABÓ, J. Anthropogenic Geomorphology: Subject and System. . In: SZABÓ, J.; DÁVID, L.; LÓCZY, D. (Eds.). Anthropogenic Geomorphology: A Guide to Man-Made Landforms. London-New York: SPRINGER Science+Business Media B.V., Dordrecht-Heidelberg, 2010. 298 p. 